\title{
Peran Dosen Penasehat Akademik (PA) Prodi Perbankan Syariah Jurusan Syariah dan Ekonomi Islam STAIN Curup Dalam Menangani Permasalahan Mahasiswa
}

\author{
Busra Febriyarni \\ Institut Agama Islam Negeri (IAIN) Curup \\ bundabusra@gmail.com
}

\begin{abstract}
This paper raises the issue of how the role of PA lecturers in solving problems of students of Islamic banking study programs majoring in Sharia and Islamic Economics. The method used in this study is field research with a qualitative descriptive approach. The source of important data in this study is the PA lecturer in the Sharia Banking study program which is also called the research informant. The results showed that students had many academic problems, including the problem of taking courses every semester there were pre and no conditions, shortages and excess credits, less cooperative or less familiar with their respective PA lecturers, problems, economics, family there are even personal problems that consult with PA lecturers. The role of PA lecturers in solving the problem of the students in the Islamic Banking study program is quite well, this can be seen from the role of PA lecturers as their student mentors in academic matters that lead to taking courses, as advisors who always remind students in several ways, such as ethical issues, not yet fluent in reading Al-Quran, and as a motivator who always gives motivation to a better future career, their parents' economic problems and their relationship to the late payment of semester fees and others. In general, PA lecturers in the Sharia banking study program have played a role as PA lecturers both as mentors, directors, advisors and motivators in the academic, social, economic and career fields.
\end{abstract}

Key Words: Academic Supervisor; Academic Guidance; Academic Activities

Abstrak
Tulisan ini mengangkat masalah bagaimana peranan dosen PA
dalam menyelesaikan permasalahan mahasiswa program studi
perbankan Syariah jurusan Syariah dan Ekonomi Islam. Metode
yang dipakai dalam penelitian ini adalah penelitian lapangan dengan
pendekatan deskriptif kualitatif. Sumber data penting dalam


penelitian ini adalah dosen PA di Prodi Perbankan Syariah yang disebut juga dengan informan penelitian. Hasil penelitian menunjukkan bahwa mahasiswa memiliki permasalahan akademik yang banyak, di antaranya adalah, masalah pengambilan mata kuliah setiap semester ada yang pra syarat dan tidak, kekurangan dan kelebihan sks, kurang kooperatif atau kurang kenal dengan dosen PA masing-masing, masalah, ekonomi, keluarga, bahkan masalah pribadi juga ada yang mengkonsultasikannya dengan dosen PA. Peranan dosen PA dalam menyelesaikan masalah mahasiswa tersebuat di prodi Perbankan syariah cukup berjalan dengan baik, ini bisa dilihat dengan peran dosen PA sebagai pembimbing mahasiswanya dalam hal akademik yang mengarahkan untuk pengambilan mata kuliah, sebagai penasehat yang selalu mengingatkan mahasiswa dalam beberapa hal, seperti masalah etika, belum lancar dalam membaca Al-Quran, dan sebagai motivator yang selalu memberikan motivasi kepada untuk karir ke depan yang lebih baik, masalah ekonomi orang tua mereka dan hubungannya dengan keterlambatan membayar uang semester dan lain-lain. Secara umum dosen PA di program studi perbankan syariah sudah melakukan peranan sebagai dosen PA baik sebagai pembimbing, pengarah, penasehat dan motivator dalam bidang akademik, sosial, ekonomi dan karir.

Kata Kunci : Dosen Pembimbing Akademis; Bimbingan Akademis; Kegiatan Akademis

\section{Pendahuluan}

Perguruan tinggi adalah pusat penyelenggaraan dan pengembangan pendidikan tinggi serta pemeliharaan, pembinaan dan pengembangan ilmu pengetahuan, teknologi atau kesenian. Kehidupan perguruan tinggi adalah kehidupan masyarakat ilmiah yang penuh dengan cita-cita luhur, masyarakat berpendidikan yang gemar belajar, dan mengabdi kepada masyarakat serta melaksanakan penelitian yang menghasilkan manfaat untuk meningkatkan mutu kehidupan masyarakat, bangsa dan negara. Pendidikan tinggi harus merupakan sistem yang dapat menyesuaikan diri dengan kebutuhan-kebutuhan masyarakat, bangsa dan negara yang senantiasa mengalami perkembangan. Sistem pendidikan tinggi diharapkan merupakan suatu sistem yang memudahkan seseorang menuntut ilmu sesuai dengan bakat, minat dan tujuannya. ${ }^{1}$

Sekolah Tinggi Agama Islam Negeri (STAIN) Curup adalah perguruan tinggi yang menyelenggarakan pendidikan akademik dan profesional, tersusun

\footnotetext{
${ }^{1}$ Tim Penyusun Buku Pedoman Akademik IAIN Curup, Pedoman Akademik dan Kode Etik Mahasiswa, 2011, h.pendahuluan.
} 
atas dasar keseluruhan dan kesatuan ilmu pengetahuan agama Islam. Program pendidikan akademik dan profesional tersebut terdiri atas 3 jurusan, yakni: Jurusan Tarbiyah dengan 6 (enam) program studi, yaitu Pendidikan Agama Islam (PAI), Pendidikan Bahasa Inggris (PBI), Bimbingan Konseling Islam (BKI), Pendidikan Bahasa Arab (PBA), Pendidikan Guru Madrasah Ibtidaiyah (PGMI) dan Manajemen Pendidikan Islam (MPI), jurusan dakwah dengan 2 (dua) program studi, yaitu Komunikasi dan Penyiaran Islam (KPI) dan Ilmu Alquran Tafsir (IQT), dan jurusan Syariah dengan 2 (dua) program studi yaitu; Ahwal al-Syakhshiyyah (Peradilan Agama) dan Perbankan Syariah (PS).

Untuk mendukung terselenggaranya pendidikan akademik tersebut STAIN Curup dilengkapi dengan berbagai unit kerja, yaitu: Jurusan,Program Studi,Bagian Administrasi, Sub Bagian Akademik dan Kemahasiswaan (AK), Sub Bagian Umum, Sub Bagian Kepegawaian dan Keuangan, Sub Bagian Perencanaan, Pusat Penelitian dan Pengabdian Masyarakat (P3M), Pusat Penjamin Mutu Pendidikan, Pusat Informasi dan Komunikasi Kerjasama, Perpustakaan dan sebagai jantungnya, dan berbagai unit pelaksana tekhnis lainnya. Walaupun secara organisasi memiliki fungsi dan yan g berbeda-beda, berbagai unit kerja ini terikat dalam satu visi dan misi. Satu sama lain terikat dalam satu tatanan kerja yang selaras dan serasi, sehingga mampu memberikan lingkungan yang kondusif bagi penyelenggaraan dan pengembangan kegiatan akademik di STAIN Curup.

Pengembangan STAIN ke depan dalam rangka cita-cita besar alih status ke STAIN sangat dituntut seluruh civitas akademika untuk bekerja sama dalam mewujudkan harapan dan cita-cita ini. Pimpinan, dosen dan tenaga kependidikan serta mahasiswa saling bekerja sama sesuai porsinya. Salah satu hal selama ini yang kurang mendapatkan lirikan dan perhatian dari pimpinan adalah tentang peranan dosen Penasehat Akademik (PA). Belum adanya panduan yang baku dan tugas yang terstruktur yang dikeluarkan oleh pihak STAIN untuk dosen PA. Mungkin secara selintas dosen PA tidak dianggap penting keberadaannya, padahal dia juga merupakan elemen kecil yang penting untuk mewujudkan kemajuan STAIN Curup. Setidaknya mampu menjadi perpanjangan tangan dari ketua program studi, jurusan dan wakil ketua bidang akademik.

Selanjutnya, yang paling berperan dalam perkembangan dan keberadaan sebuah perguruan tinggi adalah kuantitas dan kualitas dosen dan mahasiswa.Ada tiga hal yang perlu diperhatikan oleh mahasiswa untuk keberhasilan setiap mata kuliah, yaitu: pertama, menghadiri kuliah tatap muka, kedua, tugas terstruktur yang harus diselesaikan oleh mahasiswa dan, ketiga, kegiatan belajar mandiri. ${ }^{2}$ Jika mahasiswa ingin menyelesaikan ketiga hal tersebut dengan baik,di samping

2 Tim Penyusun dari Jurusan Bimbingan dan Konseling Fakultas Ilmu Pendidikan Universitas Negeri Padang (Prayitno dkk), Keterampilan Belajar, (seri latihan), 2002, h.6. 
pribadinya sendiri yang berusaha dengan optimal, juga akan dibantu oleh seorang dosen penasehat akademiknya. Begitu juga halnya dengan mahasiswa STAIN Curup perkuliahan dibimbing dan diarahkan oleh satu orang dosen Penasehat Akademik (selanjutnya disebut dosen PA).Dosen PA inilah yang diberikan tugas sebagai pembimbing dan penasehat mahasiswa dalam berbagai persoalan akademik.

Dosen Penasehat Akademik (PA) adalah Dosen atau petugas yang diserahi tanggung jawab oleh program studi untuk membimbing secara umum sejumlah mahasiswa, dan secara khusus menangani permasalahan yang lebih serius dari mahasiswa yang dibimbingnya itu. Dalam kaitan ini peranan pokok dosen PA adalah;

1. Memberikan dukungan umum kepada semua mahasiswa dengan bertindak selaku teman dan orang tua bagi mahasiswa mereka.

2. Melakukan penanganan awal.

3. Melakukan alih tangan kasus, apabila hal itu memang diperlukan. ${ }^{3}$

Sedangkan dosen PA di STAIN Curup adalah seorang tenaga pengajar yang ditunjuk dan dipercayakan oleh Ketua STAIN Curup untuk menjadi penasehat dan pembimbing mahasiswa yang diasuhnya, yang tugasnya adalah:

1. Memberikan arahan dan bimbingan kepada mahasiswa untuk menentukan mata kuliah ataupun kegiatan akademik lainnya.

2. Mendorong dan menanamkan kesadaran untuk bekerja keras dan belajar giat secara teratur, berkesinambungan dan disiplin.

3. Menumbuhkembangkan semangat mahasiswa bimbingannya melalui pertemuan individual atau kelompok.

4. Memberi bimbingan dan arahan kepada mahasiswa bimbingannya yang kurang berprestasi atau melanggar kode etik mahasiswa.

5. Mendorong dan menanamkan kesadaran mahasiswa untuk aktif dalam kegiatan kurikuler serta memberikan penilaian kegiatan ko-kurikuler yang dicapai oleh mahasiswa. Penilaian ko-kurikuler ini dilakukan setiap semester dan disahkan dengan tanda tangan dosen PA dalam buku pedoman kegiatan ko-kurikuler pada saat dilakukannnya bimbingan atau mata kuliah yang akan diambilnya.

6. Mengadakan bimbingan terjadwal dengan mahasiswa minimal 3 kali dalam satu semester, yakni awal, pertengahan dan akhir semester. ${ }^{4}$

Mengenali program studi yang diambil mahasiswa dan mengambil beban studi setiap semester merupakan tugas penting yang dilakukan dosen PA setiap memasuki semester baru. Mahasiswa berkonsultasi dengan dosen PA nya tentang mata kuliah yang diberikan di semester tersebut dan apa saja yang bisa

\footnotetext{
${ }^{3}$ Prayitno, Pengembangan Potensi Mahasiswa, Universitas Negeri Padang, 2004, h. 101-102.

${ }^{4}$ Ibid., h. 30-31.
} 
diambil sesuai dengan Indek Prestasi Semester (IPS), jika IPS lebih dari 3,504.00 maka bisa mengambil 24 sks, jika IPS 3.00-3,49 maka boleh mengambil boleh mengambil 22 sks dan jika IPS 2.50-2.99 maka boleh mengambil 20 sks, jik IPS 2.00-2,49, maka boleh mengambil18 sks, jika IPS 1.50-1.99 maka boleh mengambil 16 sks, dan jika IPS 1.00-1.49 Cuma boleh 12 sks. ${ }^{5}$ Jika mahasiswa belum memahami ini dengan baik dosen PA akan mengarahkannya.

Selanjutnya dalam hal permasalahan yang dihadapi mahasiswa selama perkuliahan seyogyanya juga dikomunikasikan dengan dosen PA nya, seperti adanya mata kuliah yang susah untuk dipahami, dosen yang jarang masuk, kesulitan dalam satu mata kuliah, belum lancarnya membaca al-Quran, mengambil cuti kuliah karena berbagai hal, keterlambatan membayar spp,dan lain-lain. Masalah ini sebagian ada yang menyampaikan kepada dosen PA nya ada juga yang tidak. Artinya mereka tidak memberdayakan dosen PA nya dengan sebaik mungkin.

Persoalan yang paling menonjol adalah banyaknya dari mahasiswa tidak kenal dengan dosen PA nya. Berhubungan dengan dosen PA hanya sebatas minta tanda tangan setiap awal semester. Itupun banyak yang terlambat, bahkan sampai kartu rencana studi mereka sampai kusam. Hal ini disebabkan karena mereka beranggapan dosen PA tidak berperan penting bagi mereka, atau sebaliknya dosen PA juga tidak perhatian dengan mahasiswa bimbingannya.

Salah satu usaha yang dilakukan di Program Studi Perbankan Syariah (PS) Jurusan Syariah dan Ekonomi Islam STAIN Curup dalam hal pemberdayaan dosen PA untuk menyelesaikan permasalahan mahasiswa adalah memberikan kesempatan kepada dosen PA untuk membimbing mereka dalam hal peningkatan membaca al-Quran dan Pratikum Ibadah. Hal ini sudah dilakukan 2 tahun ini oleh dosen PA di prodi PS. Dilanjutkan dengan mendengarkan bacaan Al-Quran, hafalan beberapa surat, hadis-hadis keprodian dan praktek ibadah sebelum mengajukan proposal, ujian komprehensif dan ujian munaqasyah, membuat pengumuman kepada mahasiswa bahwa pertemuan dengan dosen PA bisa pada hari-hari yang telah diumumkan, termasuk mengoreksi dan memberi masukan tentang proposal skripsi bagi mahasiswa yang sudah duduk semester akhir.

Persoalan lain yang sering muncul ketika di lapangan adalah kurang intensifnya pertemuan dan komunikasi antara dosen PA dan mahasiswa yang dibimbingnya. Kurang terjadualnya agenda kerja dosen PA dengan mahasiswanya. Tidak adanya SOP yang jelas tentang keberadaan dan ruang lingkup dosen PA. Tidak adanya standar penilaian dan pelaporan pertanggungjawaban dosen PA. Tidak adanya insentif yang jelas untuk dosen PA di STAIN curup. Tidak adanya kebijakan pimpinan terhadap kemajuan dosen

${ }_{5}$ Tim Penyusun buku Pedoman akademik dan Kode Etik Mahasiswa STAIN Curup, op.cit., h.44. 
PA dan bimbingan atau pelatihan yang terstruktur untuk dosen PA.Tidak adanya evaluasi per semester kepada dosen PA dari prodi, jurusan dan STAIN. Banyaknya masalah yang dihadapi oleh mahasiswa yang tidak dikomunikasikan dengan dosen PA nya baik persoalan akademik, sosial, dan ekonomi. Hal inilah yang membuat penulis tertarik untuk mengadakan penelitian tentang bagaimana "Peranan dosen Penasehat Akademik (PA) dalam menyelesaikan permasalahan akademik mahasiswa di program studi Perbankan Syariah jurusan Syariah dan Ekonomi Islam.”

Kegiatan utama mahasiswa belajar di perguruan tinggi adalah menjalani kuliah tatap muka dengan dosen. Dalam mengikuti perkuliahan tersebut berbagai aktivitas harus dilakukan mahasiswa, mulai dari pembentukan sikap terhadap kuliah, mempersiapkan diri untuk menghadiri setiap perkuliahan, mengikuti kuliah dan menindak lanjuti kegiatan tatap muka perkuliahan. Kecendrungan yang terjadi ialah banyak mahasiswa yang mengutamakan kegiatan mengikuti kuliah saja dan mengabaikan persiapan dan tindak lanjut perkuliahan. Mereka beranggapan dengan ikut hadir dalam perkuliahan saja mereka akan mampu memperoleh hasil belajar yang memuaskan. Padahal mengikuti perkuliahan, dan menindaklanjuti apa yang diperoleh mahasiswa dalam acara perkuliahan amat menentukan keberhasilan mereka.

Permasalahan penting yang dihadapi STAIN Curup berkenaan dengan prestasi mahasiswa adalah peranan dari dosen pembimbing akademik. Salah satu pointer yang menentukan keberhasilan dari mahasiswa adalah bimbingan dan arahan dari dosen pembimbing akademik mereka. Fakta yang ditemui di STAIN Curup di antaranya adalah kurangnya komunikasi antara dosen dan mahasiswa yang dibimbingnya, sehingga tidak jarang ditemukan mahasiswa yang tak kenal dengan dosen PA nya.

Dari inventaris masalah yang saya lihat terjadi di STAIN Curup adalah sebagai berikut:

1. Banyaknya mahasiswa STAIN Curup yang tidak mengenal dosen PA nya.

2. Kurangnya arahan dan bimbingan dari dosen PA masing-masing.

3. Tidak mau berkonsultasi dengan dosen PA nya tentang permasalahan kuliah.

4. Bertemu dosen PA hanya satu kali persemester.

5. Tidak adanya pedoman atau kebijakan dari STAIN tentang tugas dosen PA secara spesifik.

6. Belum adanya SOP yang jelas tentang dosen PA

7. Kurang adanya komunikasi antara dosen PA dan mahasiswa karena kesibukan masing-masing (dosen dan mahasiswa)

8. Tidak adanya evaluasi yang jelas dan laporan pertanggungjawaban dosen PA kepada siapa.

9. Kurang memahami secara mendalam tugas sebagai dosen PA oleh sebagian dosen. 
10. Memalsukan tanda tangan dosen PA ketika tidak bertemu di saat awal semester untuk isian rencana studi.

11. Banyaknya mahasiswa bimbingan masing-masing dosen PA, membuat mereka tidak bisa secara personal mengenal masing-masing mahasiswa bimbingannya.

12. Tidak adanya sangsi dan arahan dari pihak STAIN bagi dosen PA dan mahasiswa yang tidak aktif dan komunikatif dengan dosen PA nya.

13. Banyaknya dari mahasiswa STAIN yang melakukan pergaulan tidak sesuai dengan norma Islam baik di kampus maupun di luar.

14. Ada mahasiswa yang cuti kuliah karena masalah ekonomi tetapi tidak pernah dikomunikasikan dengan dosen PA nya.

Inilah beberapa identifikasi masalah yang bisa peneliti tuangkan dalam rancangan proposal ini. Sesungguhnya masih banyak kendala lain yang dihadapi dosen PA dan mahasiswa yang berhubungan prestasi akademik dan kesidiplinan kampus. Oleh karena itu penulis ingin sekali melihat secara mendalam tentang peranan dosen penasehat akademik (PA) untuk membantu permasalahan akademik mahasiswa program studi Perbankan Syariah Jurusan Syariah dan Ekonomi Islam STAIN Curup, dengan harapan bisa memberikan secercah perbaikan untuk peningkatan mutu STAIN Curup ke depan khususnya prestasi mahasiswa.

\section{Rumusan Masalah dan Batasan Masalah}

Berdasarkan beberapa identifikasi masalah di atas maka masalah pokok dalam penelitian ini adalah:

1. Apakah bentuk permasalahan akademik mahasiswa Perbankan Syariah STAIN Curup?

2. Bagaimana peranan dosen Penasehat Akademik (PA) Prodi Perbankan Syariah jurusan Syariah dan Ekonomi Islam STAIN Curup dalam menangani permasalahan mahasiswa?

\section{Batasan Masalah}

Agar penelitian ini dapat terfokus dan tidak melebar, maka peneliti akan memberikan batasan kajian seputar permasalahan apa saja yang dihadapi mahasiswa Perbankan Syariah (PS) STAIN Curup di bidang akademik (Intra dan ekstra kampus), serta peranan dosen PA dalam membantu penyelesaian masalah tersebut yang dikhususkan pada dosen PA prodi Perbankan Syariah (PS) jurusan Syariah dan Ekonomi Islam.

\section{Tujuan Penelitian dan Kontribusi (manfaat) Penelitian.}

Tujuan yang akan diungkap dalam penelitian ini adalah: 
1. Untuk mengetahui permasalahan akademik mahasiswa program studi Perbankan Syariah (PS) jurusan Syarian dan Ekonomi Islam STAIN Curup

2. Untuk mengetahui peranan dosen Penasehat Akademik (PA) prodi Perbankan Syariah (PS) Jurusan Syari'ah dan Ekonomi Islam STAIN Curup dalam menangani permasalahan mahasiswa.

Adapun manfaat yang dapat dipetik dari penelitian ini adalah:

1. Manfaat teoritis

Sebagai masukan bagi STAIN Curup dalam hal peningkatan mutu Perguruan Tinggi dalam bidang pearanan dosen PA dalam membantu menyelesaikan permasalahan mahasiswa di bisang akademik, sehingga sekelumit permasalahan tersebut bisa tercerahkan. Kemudian agar bermanfaat untuk kemajuan STAIN ke depannya.

2. Manfaat Praktis.

Secara praktis penelitian diharapkan mampu meng-optimal-kan peranan dosen PA dalam membantu permasalahan mahasiswa, sehingga terjadilah keakraban antara dosen $\mathrm{Pa}$ dengan mahasiswanya seperti orang tua sendiri, dengan tujuan dapat meningkatkan mutu dan kualitas mahasiswa.

\section{Kerangka Teori}

Dosen penasehat akademik adalah petugas yang diserahi tanggung jawaboleh program studi untuk membimbing secara umum sejumlah mahasiswa , dan secara khusus menangani penanganan yang lebih serius dari mahasiswa yang dibimbingnya itu. ${ }^{6}$ Setiap mahasiswa mempunyai seorang pembimbing atau penasehat akademik (PA), yang ditetapkan oleh ketua program studi masingmasing. Di antara tugas PA secara umum adalah:

1. Mengarahkan mahasiswa dalam menyusun rencana studi dan memberikan pertimbangan kepada dalam memilih mata kuliah yang akan diambil.

2. Memberikan pertimbangan kepada mahasiswa tentang banyaknya satuan kredit semester (sks) yang akan diambil.

3. Mengikuti perkembangan studi mahasiswa yang dibimbingnya. ${ }^{7}$

Selanjutnya format pelayanan PA terhadap mahasiswa yang dibimbingnya terentang dalam tiga kemasan pokok, yaitu volume penugasannya, aspek kegiatannya, dan sisi-sisi kelembagaannya.

1. Volume penugasan.

Volume penugasan PA meliputi jumlah mahasiswa yang dibimbing dan daerah pembimbingannya.

\footnotetext{
${ }^{6}$ Prayitno, loc.cit.,

${ }^{7}$ Universitas Indonesia, Himpunan Peraturan Akademik, 2008, h.218.
} 
a. PA ditugasi untuk membimbing mahasiswa dengan rasio1 : 10/20, artinya seorang PA ditugasi membimbing 10 sampai 20 orang mahsiswa.

b. PA membimbing mahasiswa yang sejurusan dan seangkatan

c. PA membimbing mahasiswa dari awal program studi sampai mereka diwisuda.

d. Tugas pokok PA adalah membimbing mahasiswa dari satu semester ke semester berikutnya untuk berbagai bahan pokok, sepert tentang prodi yang diambilnya, sikap, kebiasaan dan keterampilan belajar, penguasaan materi kuliah, masalah pribadi dan lain-lain.

e. Bekerja sama dengan mata kuliah untuk mengatasi permasalahan perkuliahan.

2. Aspek kegiatan

PA diharapkan dapat melakukan kegiatan ke-PA-annya melalui pertemuan dengan mahasiswa, dengan rambu-rambu sebagai berikut:

a. Pertemuan dilakukan minimal 3 kali setiap semester. Setiap kali pertemuan dibuat laporan pertemuan yang berisi daftar hadir, pokok yang dibicarakan, dan hasil pertemuan.

b. Kesempatan pertemuan, terjadual (tiga kali persemester), pertemuan atas perjanjian dengan mahasiswa, dan pertemuan insidental yang dikehendaki oleh PA atau mahasiswa.

c. Format pertemuan disesuaikan dengan kesempatannya. ${ }^{8}$

3. Sisi Kelembagaan berikut:

Penugasan PA perlu dilembagakan dengan memperhatikan hal-hal

a. Penugasan secara resmi oleh ketua program studi melalui Surat Keputusan (SK) tersendiri.

b. PA diminta memberikan pertanggungjawaban atas pelaksanaan tugas setiap semester.

c. Imbalan. Penugasan PA setiap semester dihargai dengan sama dengan dosen yang mengampu mata kuliah dengan bobot 2 sks, dalam hal ini PA layak untuk dimintai pertanggungjawaban atas pelaksanaan tugasnya, sebagaimana layaknya dosen yang mengampu mata kuliah.Penugasan PA dihargai sebagai point tersendiri untuk kenaikan pangkat. Jika mungkin juga penghargaan dalam bentuk lain diberikan kepada dosen PA.

d. Perlu dibentuk koordinator PA untuk mengkoordinasikan pelaksanaan tugas semua PA pada program studi. Melalui 
koordinator, penugasan, kegiatan dan pertanggung jawaban PA dapat lebih tertangani. ${ }^{9}$

Selanjutnya juga akan diuraikan permasalahan mahasiswa yang bisa dibantu penyelesaiannya oleh dosen PA di antaranya adalah ditinjau dari proses pengembangannya, mahasiswa umumnya berada pada akhir masa remaja dan awal masa dewasa. Masa ini ditandai dengan berbagai perubahan yang cepat dalam aspek biologi, intelektual, emosi, nilai dan sikap menuju ke arah kematangan dan kemantapan kepribadian. Dengan demikian, masa belajar di perguruan tinggi merupakan masa transisi, sebagai kepribadian yang mantap dalam masa dewasa.

Berdasarkan hasil bacaan dan perbandingan penulis tentang masalahmasalah yang sering dialami mahasiswa adalah:

1. Masalah yang berhubungan dengan pendidikan;

a. Masalah konsentrasi. Banyak mahasiswa mengeluh karena tidak bisa konsentrasi, sehingga hasil belajar tidak maksimal. Sebabnya bermacammacam, dapat dari diri mahasiswa sendiri atau luar dirinya, seperti perasaan sepi, dorongan ingin pulang, konflik dengan lingkungannya.

b. Masalah yang berhubungan dengan sistem pengajaran, yaitu kesulitan mengikuti kuliah, membaca buku sumber berbahasa asing dan lain-lain.

c. Masalah tidak menyukai mata kuliah atau dosen tertentu. Jika mahasiswa tidak menyukai dosen tertentu atau mata kuliah tertentu, ia cenderung tidak mau mengikuti kuliah.

d. Masalah daya tahan dan kelangsungan studi. Ada mahasiswa yang mudah kecewa karena nilai yang rendah kemudian putus asa dan ingin berhenti kuliah, tidak tahan jauh dari orang tua, konflik-konflik pribadi dan karena ketegangan emosional.

2. Masalah penyesuaian diri dan hubungan sosial;

a. Kesulitan mencari teman. Ada mahasiswa yang canggung dalam pergaulan dan tidak tahu yang harus dilakukan, rasa rendah diri atau malu.

b. Penyesuai diri terhadap kehidupan kampus. Mahasiswa baru biasanya tidak tahu banyak soal tata cara kehidupan kampus dan mereka memerlukan berbagai informasi dan bimbingan.

c. Kesulitan menyesuaian diri dengan adat istiadat dan norma-norma lingungan di mana mahasiswa tinggal.

d. Konflik dengan teman sekamar, seasrama atau sejurusan. Ini terjadi biasanya karena berselisih faham atau karena kekecewaan kawan. 
3. Masalah-masalah yang sifatnya pribadi;

a. Masalah konflik dengan pacar atau pacar yang tidak disetujui orang tua.

b. Masalah pertentangan dengan anggota keluarga.

4. Masalah ekonomi;

Banyak mahasiswa yang mendalami kesulitan ekonomi karena kiriman uang yang terlambat, uang tidak cukup atau tidak dapat mengatur keuangan.

5. Masalah memilih jurusan, jabatan dan masa depan.

Ada mahasiswa yang salah pilih jurusan dan ingin pindah, ada yang masuk jurusan tertentu karena keinginan orang tua, ada yang merasa masa depannya tak menentu dan tidak tahu apa yang akan diperbuat. ${ }^{10}$

Dari teori yang sudah dikemukakan di atas, maka inilah yang akan menjadi pijakan peneliti dalam melakukan kajian selanjutnya.

\section{Studi Kepustakaan}

Penelitian berjudul Peran Pembimbing Akademik Dalam Mengoptimalkan Hasil Studi Mahasiswa: Studi Pada Politeknik Negeri Jakarta oleh Hafiduddin dan Nur Hasyim Jurusan Akuntansi Politeknik Negeri Jakarta, ${ }^{11}$ menginvestigasi peran pembimbing akademik dalam mengoptimalkan hasil studi: studi kasus pada Politeknik Negeri Jakarta.Penelitian dilakukan dengan pendekatan penelitian kualitatif, dengan kuesioner sebagai metode pengumpulan data dan analisis deskriptif sebagai metode analisis data. Hasil penelitian menunjukkan bahwa pembimbingan akademik memiliki peran yang sangat penting dan perannya mampu memotivasi mahasiswa dalam belajar. Pembimbingan perlu dilakukan lebih sering dan perlu disiapkan tempat khusus untuk pembimbingan. Peran yang telah dilakukan oleh pembimbing akademik antara lain adalah membantu mahasiswa agar mahasiswa memiliki sikap dan perilaku belajar yang baik, memberikan perhatian kepada mahasiswa yang tingkat kehadirannya rendah agar mahasiswa tidak terkena droup out (DO), dan memberikan bimbingan pada mahasiswa agar mahasiswa dapat mengembangkan potensi pendidikan, penelitian, seni dan budaya.

Makalah berjudul Peran \& Fungsi Dosen Penasehat Akademik oleh Mulyadi, Tenaga Kependidikan STAIN Malang (sekarang UIN Maliki Malang), menerangkan bahwa peran dan fungsi dosen PA adalah sebagai pembimbing, penasehat, dan motivator. Peran sebagai pembimbing yaitu membantu mahasiswa menyusun program studi secara menyeluruh maupun per semester,

10 Mulyadi, Peran dan fungsi Dosen Penasehat Akademik, (Makalah) 2002, h.5 (http://psikologi.uin-malang.ac.id/wp-content/uploads/2014/03/Peran-dan-Fungsi-DosenPenasehat-Akademik.pdf)

${ }^{11}$ Hafiduddin dan Nur hasyim, artikel Peran Pembimbing Akademik Dalam Mengoptimalkan Hasil Studi Mahasiswa: Studi Pada Politeknik Negeri Jakarta, 2013, h. abstrak 
menetapkan beban studi per semester, meneliti dan memberikan persetujuan terhadap KRS dan memberikan informasi tentang pengalaman belajar. Peran sebagai penasehat belum terlaksana secara baik karena sebagian besar dosen PA belum membantu memecahkan kesulitan belajar, belum mengembangkan sikap profesional pendidik, belum mengembangkan sikap perilaku dan kebiasaan belajar yang baik dan belum membina mengembangkan kepribadian mahasiswa sesuai dengan visi, misi dan falsafah bangsa.

Artikel berjudul Peran Penasehat Akademik Terhadap Kesuksesan Mahasiswa Di Perguruan Tinggi oleh Jum Anidar, dosen Fakultas Tarbiyah STAIN Imam Bonjol Padang menganalisis kesuksesan mahasiswa mencakup 3 hal yaitu ; kesuksesan akademik, kesuksesan perencanaan karier dan kesuksesan sosial kemasyarakatan. Penasehat akademik merupakan salah satu pihak yang mempunyai tanggung jawab terhadap kesuksesan mahasiswa. Tugas penasehat akademik adalah: a) memberi pertimbangan kepada mahasiswa untuk memilih mata kuliah yang akan diambilnya pada semester tertentu, b) memberi bimbingan dan nasehat yang bertujuan untuk membantu mahasiswa dalam mencapai prestasi belajar optimal, c) memberi penjelasan dan petunjuk tentang perkuliahan, d) memberi peringatan kepada mahasiswa yang berprestasi rendah, e) mengikuti dan memperhatikan segi-segi perilaku mahasiswa, f) menyediakan waktu yang cukup untuk berkonsultasi dengan mahasiswa di kampus, g) menandatangani kartu rencana studi mahasiswa (KRSM), h) meneliti serta menandatangani SKEK (satuan kredit ekstra kurikuler). ${ }^{12}$

Dari beberapa tulisan yang sudah penulis sebutkan di atas, maka fokus penelitian yang akan peneliti bahas adalah, bagaimana peranan dosen PA dalam membantu menyelesaikan permasalahan akademik mahasiswa program studi Perbankan Syariah jurusan Syariah dan Ekonomi Islam STAIN Curup. Penelitian ini akan diawali dengan penginventarisan berbagai masalah akademik mahasiswa, setelah itu akan dilihat bagaimana peranan dosen PA mereka dalam membantu menyelesaikan masalah tersebut, sehingga keberhasilan selama kuliah tidak hanya ditentukan oleh faktor individu mahasiswa yang bersangkutan, tetapi juga tak terlepas dari bantuan, bimbingan dan dukungan dari dosen PA nya. Selama menjadi tenaga pengajar di STAIN Curup kurang lebih 15 tahun, belum ada penelitian tentang hal ini, maka tulisan ini sangat penting untuk dilanjutkan, dengan harapan adanya komunikasi yang harmonis antara dosen PA dengan mahasiswa bimbingannya selama proses perkuliahan, serta adanya perhatian yang cukup dari pimpinan STAIN Curup tentang kebedaan dosen PA ini.

12 Jum Anidar, Peran Penasehat Akademik Terbadap Kesuksesan Mahasiswa Di Perguruan Tinggi oleh Jum Anidar, dosen Fakultas Tarbiyah IAIN Imam Bonjol Padang, dalam Jurnal AlTa'lim, Jilid 1, Nomor 3 November 2012, blm. 216-223 


\section{Hasil Dan Pembahasan}

\section{Permasalahan Akademik Mahasiswa Prodi Perbankan Syari'ah STAIN Curup}

Seperti yang sudah dijelaskan pada Bab sebelumnya, dosen penasehat akademik (PA) adalah dosen yang ditunjuk oleh ketua Jurusan atau Prodi untuk memberikan bimbingan studi kepada mahasiswa dalam rangka mencapai hasil belajar atau akademik yang maksimal dengan waktu yang telah ditentukan. Untuk memberikan pelayanan studi sebaik-baiknya kepada mahasiswa.

Bimbingan akademik yang diakukan oleh PA adalah semua kegiatan yang diarahkan untuk membantu mahasiswa di dalam menyelesaikan studinya, antara lain membimbing pengambilan beban studi pada setiap awal semester, membimbing mahasiswa dalam memecahkan berbagai masalah yang dihadapi, membimbing mahasiswa dalam kegiatan-kegiatan lain yang dipandang perlu. Bimbingan mencakup 2 (dua) segi kehidupan mahasiswa, yaitu segi akademik dan segi non-akademik. Segi Akademik yang bersangkutan dengan penyusunan program belajar (rencana studi) yang tepat, pengarahan dan nasihat dalam mengikuti kegiatan-kegiatan akademik, pengarahan dan mengembangkan sikap dan kebiasaan belajar yang baik. Segi non-akademik yaitu hal-hal di luar bidang akademik yang dianggap mempengaruhi kelancaran studi mahasiswa.

Namun faktanya, peran yang telah ditetapkan tersebut belum mencapai hasil yang diharapkan, untuk melihat lebih dalam kenyataan tersebut peneliti melakukan wawancara kepada beberapa dosen penasehat akademik (PA) di prodi Perbankan Syari'ah Jurusan Syari'ah dan Ekonomi Islam Sekolah Tinggi Agama Islam Negeri (STAIN) Curup.

Dalam menyelesaikan masalah akademik, hampir mayoritas mahasiswa bimbingan dosen penasehat akademik (PA) tidak pernah menyampaikan masalah yang mereka hadapi kepada dosen PA yang bersangkutan, seperti penjelasan dengan responden 1 yang mengatakan bahwa:

"belakangan ini hampir tidak ada permasalahan yang disampaikan mahasiswa kepada dosen penasehat akademik."13

Begitu juga pemaparan responden 2, "mahasiwa tidak pernah konsultasi permasalaban akademik, hanyak sekedar meminta tanda tangan KRS, KHS, perpindahan prodi dan judul prosposal skripsi”. ${ }^{14}$

Dalam hal memilih mata kuliah yang diambil setiap semesternya, beberapa mahasiswa pernah konsultasi dengan dosen penasehat akademik dan ada juga yang tidak pernah, seperti yang dijelaskan kedua responden di atas; pernah beberapa mahasiswa konsultasi masalah mata kuliah yang diambil setiap semester, biasanya materi yang ada pra syarat.

13 Wawancara, Abdul Hamid

14 Dwi Sulastyawati 
Permasalahan ekonomi terkadang menjadi hal yang signifikan bagi mahasiswa dalam menyelesaikan studinya, namun ada mahasiswa yang aktif hanya sekedar konsultasi kepada dosen akademik namu ada juga yang enggan untuk menceritakan hal tersebut kepada dosen PA nya.

Hal tersebut dapat dilihat dari hasil wawancara peneliti pada pertanyaan kelima; apakah ada dari mahasiswa bimbingan bapak/ibu yang mengeluhkan masalah ekonomi atau finansial orang tuanya?

"ada mahasiswa yang konsultasi",15

"belum pernab ada yang konsultasi masalah ekonomi"'16

Sebagai perguruan Tinggi yang berbasis Islam secara umum, dan khususnya Jurusan Syari'ah dan Ekonomi Islam, kemampuan membaca AlQur'an bagi setiap mahasiswa di Prodi Perbankan Syari'ah menjadi sebuah keharusan, namun faktanya ada beberapa mahasiswa yang belum mampu membaca Al-Qur'an dengan baik bahkan tidak bisa sama sekali. Maka peran dosen PA untuk memperbaiki dan meningkatkan qira'ah mereka dengan baik juga menjadi perhatian walaupun tidak keharusan. Akan tetapi mahasiswa yang bersangkutan kurang inisiatif untuk konsultasi ke dosen PA bersangkutan. Seperti wawancara dengan dosen PA dengan pertanyaan; jika ada mahasiswa bimbingan bapak/ibu yang tidak bisa membaca al-Qur'an apa saran yang Bapak/Ibu berikan kepada mereka?

"mereka harus membaca al-Qur'an",17

"agar menyediakan waktu untuk mempelajari al-Qur'an, bisa dengan cara berkelompok atau belajar secara khusus dengan guru ngaji,18 mereka"19

"mencoba memberikan pengarahan untuk mencari guru ngaji yang bisa mengajari

Dalam beberapa kasus, banyak mahasiswa yang berkonsultasi masalah lain kepada dosen penasehat akademik, artinya bahwa mereka benar-benar memposisikan dosen PA sebagai pengganti orang tua mereka ketika di kampus atau menjadikan dosen PA sebagai konselor, sebagaimana hasil wawancara dengan 3 orang dosen PA, ada beberapa mahasiswa yang konsultasi masalah keluarga dan ada juga yang konsultasi masalah perjodohan, bahkan ada yang tidak pernah sama sekali.

"mahasiwa pernah konsultasi masalah keluarga dengan dosen PA",20

\footnotetext{
15 Abdul Hamid

16 Dwi Sulastyawati

17 Noprzial

18 Abdul Hamid

19 Mashudi

20 Noprizal
} 
"diantaranya, ada juga mahasiswa yang pernah membicarakan masalah perjodohan, atau akan melaksanakan pernikahan"21

"belum ada sama sekali"22

\section{Peranan Dosen Penasehat Akademik (PA) dalam menangani masalah mahasiswa}

Masalah yang dihadapi mahasiswa sangatlah polemik, tidak ada hanya masalah akademik tetapi masalah-masalah lain, seperti masalah keluarga, ekonomi dan karir ke depan. Maka peran dosen penasehat akademik (PA) sangatlah dibutuhkan untuk memecahkan masalah-masalah tersebut. Faktanya, peran yang diharapkan tersebut belum berjalan sesuai harapan, salah satu faktornya adalah masih minimnya program yang dilakukan dosen PA tersebut, seperti hasil wawancara yang dilakukan peneliti ke beberapa dosen PA.

Dari pertanyaan, apa saja program yang bapak/ibu lakukan untuk memberikan bimbingan kepada mahasiswa bimbingannya setiap semester? Jawaban dari responden "tidak ada program khusus yang dilakukan",23 dan responden lain menjawab "banya menjelaskan kedudukan mata kuliab".

Selain menangani masalah akademik, peran dosen penasehat akademik juga diharapkan bisa menyelesaikan masalah lain yang dihadapi mahasiswa bimbingannya, ada dosen PA yang sudah berusaha untuk menyelesaikan masalah yang dihadapi mahasiswa, namun ada juga yang belum pernah dikarenakan mahasiswa yang bersangkutan tidak pernah konsultasi dengan dosen PA. Identifikasi di atas bisa dilihat dari pertanyaan wawancara peneliti; selama menjadi dosen PA, apa saja yang sudah Bapak/Ibu lakukan untuk menangani permasalahan mahasiswa yang dibimbing?

"mahasiswa yang kurang mampu diberikan arahan dan petunjuk untuke mendapatkan beasiswa tidak mampu,25

"belum ada, karena mabasiswa belum ada konsultasi"26

"mengarahkan dan meminta untuk bisa lebih optimal menggunakan waktu belajar (masa studi) $)^{, 27}$

"berkenaan dengan perkuliahan memberikan motivasi dan bimbingan,"28

Sesungguhnya peran dosen penasehat akademik di kampus Sekolah Tinggi Agama Islam Negeri (STAIN) Curup belum berjalan secara optimal,

\footnotetext{
21 Abdul Hamid

22 Istan

23 Abdul Hamid

${ }^{24}$ Noprizal

25 Abdul hamid

${ }^{26}$ Dwi Sulastyawati

27 Mashudi

28 Istan
} 
salah satu penyebabnya karena masih banyak cara pandang yang berbeda di antara dosen PA tersebut dan kurangnya perhatihan khusus dari pimpinanan secara kelembagaan.

Maka setelah melakukan wawancara dengan beberapa dosen penasehat akademik, maka peneliti menemukan jawaban dan pendapat yang berbeda-beda dari dosen PA dengan pertanyaan; bagaimana menurut bapak/ibu peranan kita sebagai dosen $\mathrm{PA}$, sebagai pembimbing, penasehat atau motivator?

"peran dosen $P A$ sebenarnya sangat strategis, untuk mengarabkan, membimbing dan memberikan motivasi terbadap mahasiswa. Tapi, peran ini kurang berjalan sebagaimana mestinya, disebabkan berbagai masalah, seperti; kurang atau tidak tersedianya waktu konsultasi mahasiswa ${ }^{, 29}$

"memberi nasehat, membimbing dan memberikan motivasi"

"ketiganya; sebagai pembimbing, membimbing mereka dalam mengikuti dan mengambil mata kuliah. Sebagai penasehat, memberikan nasehat terbadap aktivitas mereka, terlebih kalau menyangkut hal-bal yang berbubungan dengan norma dan aturan kampus. Sebagai motivator, memberikan semangat dan motivasi kepada mereka untuk berhasil dengan baik dalam kegiatan studi, di masyarakat dan dunia kerja ke depan". ${ }^{31}$

Selain dari tiga peran di atas; pembimbing, penasehat dan motivator, ada peran lain yang disampaikan beberapa dosen PA dalam wawancara peneliti, seperti yang dijelaskan Abdul Hamid bahwa selama ini banyak mahasiswa yang kurang mengerti bahkan tidak faham peran dan tugas dosen PA terhadap mahasiswa, maka penjelasan tentang hal tersebut perlu dijadikan materi wajib dalam kegiatan Orientasi Pengenalan Kampus (OPAK). ${ }^{32}$

Penjelasan lain oleh Muhammad Istan, selain dari tiga peran yang sudah dijelaskan di atas, sebagai dosen penasehat akademik perlu memposisikan diri sebagai saudara mahasiswa yang bersangkutan, sehingga memudahkan komunikasi dengan mahasiswa tanpa ada sekat yang membatasi. ${ }^{33}$ Dosen PA semaksimal mungkin bisa memposisikan diri sebagai orang tua, bahkan sebagai sahabat dari mahasiswa yang bersangkutan. ${ }^{34}$

Maka untuk mengoptimalkan peran dan fungsi dosen penasehat akademik (PA) di kampus Sekolah Tinggi Agama Islam Negeri (STAIN) Curup, perlu adanya perhatian dan kebijakan khusus dari unsur pimpinan, karena selama ini hal tersebut belum terlihat jelas sehingga berdampak pada kurangnya mobilisasi peran dan tugas dosen PA tersebut. Hal tersebut bisa dilihat dari hasil wawancara dengan beberapa dosen PA, dengan pertanyaan; menurut bapak/ibu

\footnotetext{
29 Abdul Hamid

30 Mashudi

31 Istan

32 Wawancara Abdul Hamid, .....

33 Wawancara Muhammad Istan, .....

34 Wawancara Noprizal, .......
} 
bagaimana kebijakan STAIN Curup tentang dosen PA dan hal-hal yang berkaitan dengan peran dan fungsi dosen PA selama ini?

"STAIN Curup belum mematubi ketentuan dari Kemenag tentang peran dan bake PA, terlebih surat dari Kemenkeu ke Kemenag (S/MK-39-2015). ${ }^{35}$

"yang berbubungan dengan pembinaan dirasakan kurang, dan yang berbubungan dengan kesejabteraan belum ada perbatian di tabun 2015 ini. ${ }^{\prime 36}$ akademik." ${ }^{37}$

"tidak ada perhatian yang memadai, termasuk memfungsikan dosen penasehat

"Sesunggubnya sudah ada perhatian tapi sangat minim, mungkin dikarenakan kegiatan dan jadwal yang over dari pimpinan". ${ }^{38}$

Dari berbagai argumen informan di atas, maka perlu adanya komunikasi yang baik dan terukur dari dosen penasehat akademik kepada mahasiswa, dilanjutkan perlu adanya perhatian dari pihak pimpinan tentang standar kerja dan tugas yang jelas dari dosen PA tersebut. Hal ini sangat dibutuhkan dalam rangka sumbangsih para dosen dan mahasiswa untuk percepatan alih status dari STAIN menuju IAIN.

\section{Kesimpulan}

Dari pemaparan dan hasil wawancara yang telah dilakukan peneliti kepada beberapa dosen penasehat akademik (PA) di Prodi Perbankan Syari'ah Jurusan Syari'ah dan Ekonomi Islam Sekolah Tinggi Agama Islam Negeri (STAIN) curup, dapat disimpulkan sebagai berikut;

1. Pada dasarnya setiap mahasiswa memiliki permasalahan akademik yang berbeda-beda, di antaranya masalah pengambilan mata kuliah, pra syarat dan mata kuliah lepas (tidak bersyarat), masalah kekurangan dan kelebihan sks yang diberikan setiap semester dikaitkan dengan IPS setiap mahasiswa sudah banyak yang menyampaikan secara langsung kepada dosen PA masing-masing, namun juga masih ada dari mahasiswa yang kurang kooperatif dengan dosen PA yang telah ditetapkan dengan alasan yang belum dapat teridentifikasi. Namun pada masalah lain, seperti; masalah ekonomi, keluarga bahkan masalah pribadi ada beberapa mahasiswa yang pernah konsultasi dengan dosen penasehat akademik mereka.

2. Peranan dosen penasehat akademik di prodi Perbankan Syari'ah Jurusan Syari'ah dan Ekonomi Islam sudah cukup berjalan dengan baik, ini bisa ditunjukkan dengan peran dosen PA sebagai pembimbing yang selalu membimbing mahasiswanya dalam hal akademik, sebagai penasehat yang selalu menasehati mahasiswa dalam beberapa hal, seperti; masalah etika dan

\footnotetext{
35 Noprizal

36 Muhammad Istan

37 Abdul hamid

38 Dwi Sulastyawati
} 
moral, dan mahasiswa yang belum baik dalam membaca al-Qur'an, dan sebagai motivator yang selalu memberikan motivasi kepada mahasiswa untuk karir ke depan yang lebih baik, masalah ekonomi orang tua mereka dan hubungannya dengan keterlambatan membayar uang semester dan lainlain. Secara umum dosen Penasehat Akademik di program studi Perbankan Syariah sudah melakukan peranan mereka sebagai dosen PA baik sebagai pembimbing, pengarah dan motivator dalam bidang akademik, sosial, ekonomi dan karir. 


\section{Daftar Pustaka}

Anidar, Jum, Peran Penasehat Akademik Terhadap Kesuksesan Mahasiswa Di Perguruan Tinggi oleh Jum Anidar, dosen Fakultas Tarbiyah STAIN Imam Bonjol Padang, dalam Jurnal Al-Ta'lim, Jilid 1, Nomor 3 November 2012

Basuki, Sulistyo, Metode Penelitian, Jakarta: Wedatama Widya Sastra bekerjasama dengan Fakultas Ilmu Pengetahuan Budaya Universitas Indonesia, 2006

Burhan Bungin ed. Metodologi Penelitian Kualitatif, Aktualisasi Metodologiske Arah Ragam Varian Kontemporer, (Jakarta: PT. Raja Grafindo Persada, 2007)

Hafiduddin dan Hasyim, Nur, Peran Pembimbing Akademik Dalam Mengoptimalkan Hasil Studi Mahasiswa: Studi Pada Politeknik Negeri Jakarta, 2013

Muhajir, Noeng, Metodologi Penelitian Kualitatif, (yogyakarta: Rake Sarasin, 1992)

Mulyadi, Peran dan fungsi Dosen Penasehat Akademik, (Makalah) 2002, (http://psikologi.uin-malang.ac.id/wpcontent/uploads/2014/03/Peran-dan-Fungsi-Dosen-PenasehatAkademik.pdf)

Nasir, Moh., Metodologi Penelitian, (Jakarta: Ghalia, 1998)

Prayitno, Pengembangan Potensi Mahasiswa, Universitas Negeri Padang, 2004

Sukardi, Metodologi Penelitian Pendidikan, (Jakarta: Bumi Aksara, 2003)

Tim Penyusun Buku Pedoman Akademik STAIN Curup, Pedoman Akademik dan Kode Etik Mahasiswa, 2011

Tim Penyusun dari Jurusan Bimbingan dan Konseling Fakultas Ilmu Pendidikan Universitas Negeri Padang (Prayitno dkk), Keterampilan Belajar, (seri latihan), 2002

Universitas Indonesia, Himpunan Peraturan Akademik, 2008 
152 | ISLAMIC COUNSELING: Jurnal Bimbingan dan Konseling Islam, vol. 2, no. 2, 2018 